\title{
Influence of Creditor Stakeholder Pressure, Media Coverage and Industry Groups on Quality of Social and Environmental Disclosure in Indonesian Companies
}

\author{
Lilis Suryani \\ Luk Luk Fuadah \\ Yusnaini \\ University of Sriwijaya \\ Accounting Department \\ Indonesia
}

\begin{abstract}
This study aims to examine the influence of creditor stakeholder pressure, media coverage and industry groups on the quality of corporate social and environmental disclosure. This research analysis uses a panel data regression analysis method. The research sample consisted of 85 companies that go public PROPER participants who are consistent every year and are listed on the IDX for the period 2014-2018. The results found that the industry group, company size, and profitability as a control variable has a positive effect on the quality of social disclosure and the environment. The results also showed that the pressure from creditor stakeholders and coverage the media has no effect on the quality of social and environmental disclosure. Quality, not all social disclosure and corporate environmental go public of PROPER participants are not all quality but quality improvement every year given the importance of profit, social and environmental sustainability for the company in the future.
\end{abstract}

Keywords: Creditor pressure, disclosure quality, industry groups, media exposure.

\section{Introduction}

Accounting studies examine the issues of sustainability (sustainable development) of the company, in general, focuses on environmental disclosure practices and those that have an influence on levels disclosure of environmental accounting (Mansor et al., 2016; Lindawati and Puspita, 2015). Consequence social and environmental causes of agencies become a source of global concern resulting in the emergence of the concept of Corporate Social Environment Disclosure (CSED) (Macarulla and Talalweh, 2012; Bewley and Griffiths, 2000; Patten, 1992; Ulmann, 1985). Important issue social and environmental disclosure is a challenge and concern of many countries, especially in developed countries both academics and business executives (Nguyen et al., 2017; Macarulla and Talalweh, 2012). Basically, both are considered to have a positive relationship due to profit that the company obtained is no longer the only way to measure company performance (Bani-khalid et al., 2017; Sanghiata et al., 2015). The results of research conducted by Jambeck et al. (2015), researchers from Georgia University, named Indonesia as the second largest contributor to plastic waste to the world sea. It is estimated that plastic waste from Indonesia entering the sea is 0.48 1.29 million metric tons per year. In 2016 and 2017 Greenpeace Indonesia said Nestle had accounted for 1.7 tons of plastic which eventually polluted the environment. Besides Nestle, the company another giant is Unilever of 610,000 metric tons of plastic to package products its products and their waste ends up not biodegradable. Greenpeace also mentioned more than $90 \%$ of the plastic produced is never recycled, but the corporation plans to drastically increase the production of plastic packaging The development of environmental issues awareness by the Government of Indonesia through the Ministry of the environment in PROPER 1995.

Measurement using color measurements. Gold color show more environmental management than is required and make efforts sustainable community development. The green color is the company that has conduct environmental management consistently. Blue indicates you have done its management according to minimum requirements. The red color indicates that the company has made management efforts but only in part. Black ranks lowest in managing the environment which means it has not made management efforts. The color is useful to motivate many companies to care about the environment and management and the development of community life around the company (Ministry of Environment Live, 2011). 
The company's dependence on creditors today will motivate companies to improve income (debt) (Roberts, 1992). One of the strategies carried out is to carry out activities and CSR disclosures to give creditors confidence to improve performance so that there is a certainty for creditors if the company will pay their receivables (Lee et al., 2013).

Media reporting is part of public scrutiny which puts pressure on the company to be more concerned with the issue of responsibility so that it gives encouragement to companies to disclose more responsibilities (Widiastuti et al., 2018). Media coverage of companies can influence public opinion. Companies that have the potential to have a high environmental impact, tend to will publish information about social responsibility more transparently (Hamudiana and Achmad, 2017).

Gamerschlag (2011) argues that CSR will be disclosed more if the company within the scope of environmental group pressures. Issues regarding environmental damage and social impacts caused by the company so researchers are interested to see the effect of quality corporate social and environmental disclosure as a form of responsibility. This research continues the development of quality CSR information disclosures where disclosure conducted that is still varied, the average is still below and close to $50 \%$ (Widiastuti et al., 2018). There is a difference from the results of the study each variable revealed by previous researchers generates interest in doing research again.

\section{Literature Review}

Effect of Creditor Pressure on the Quality of Social and Environmental Disclosures Creditors have an interest in the company for loans. Financial resources that capital to continue the company's business activities in which there is also a role (Roberts, 1992). The bank as one of the creditors is included in the financing institution who conducts an analysis of the social environment in the loan approval process. Bank follows the analysis step as the existing credit assessment process currently in effect at banking despite the absence of regulations governing environmental risk analysis (Panjaitan, 2015). The results of Purnasiwi and Sudarno's research (2011) suggest a relationship between the level of debt to social disclosure. Research by Lu and Abeysekera (2014) found that pressure from creditors continued to influence their CERD even though generally seem weak. Stakeholder theory says that company activities can be influenced by many people can instead provide a response back. Stakeholders who have an important role in organizations such as employees, suppliers, consumers, creditors, governments and the public must buy the company regarding the values of its stakeholders. Creditors as external stakeholders have a role to pressure the company to get information about the entire performance of the company such as economic, social and environment. Through quality company disclosures, it means that companies can show responsibility, then the creditor's trust to provide capital can be obtained, from an environmental social risk analysis conducted by the creditor.

\section{H1: Creditor's pressure positively influences the quality of social}

\section{The Effect of Pressure on Media Coverage on the Quality of Social and Environmental Disclosure}

Media reporting is part of public scrutiny that provides pressure and encouragement to companies to be more concerned about the issue of their responsibility (Widiastuti et al., 2018). The media as part of external stakeholders can influence the views of all people about the company. As a result of the media coverage made the name good company because of the pressure coming from the media makes the company always maintains the image to always look good and good (Solikhah et al., 2016). Access to media affects the level of consumption of goods and services produced by the company because of the ability of the media. This is proven in research (Reverte, 2009; Rupley, et al., 2012; Tan et al., 2016; Hasnia and Rofingatun, 2017; Wang and Wang, 2018) find the index CSR disclosure and the quality of corporate environmental disclosure are affected by coverage media. Based on the theory of legitimacy, the company carries out social activities desired by the community in order to get an award and also be able to carry on the company's life. The theory of legitimacy is used to explain the reason companies disclosing environmental information voluntarily are for accountability and visitability as a way to legitimize the activities of companies that they have been responsible for the answer according to social expectations and norms. If the company feels pressured and afraid of its negative news, the company will try to increase its responsibilities in the quality of social and environmental disclosure.

\section{H2: Media coverage has a positive effect on the quality of environmental social disclosure} The Influence of Environmental Sensitive Industry Groups on the Quality of Social Disclosure and the environment

Companies that have the potential to have a high environmental impact, tend to publish information about social responsibility more transparently and quality. This happened because they tried to get support from the stakeholders. Deegan and Gordon (1996) found an increase in voluntary CSR reporting conducted to get support from the stakeholders regarding the company's activities in an environmentally insensitive industry. The company will make more disclosures if included in environmental group pressure (Gamerschlag, et al 2011). 
Negative views of society due to environmental pollution by industry can be reduced by conducting transparency reporting (Fernandez Feijoo et al., 2012).

According to the concept of the $3 p$ bottom line theory say profit/economy, social and environment must be balanced and stakeholder theory the environment includes the company's external stakeholders who need corporate responsibility as well. Companies that are sensitive to the environment can already be said to balance responsibility economic, social and environmental responsibility for the company's sustainability.

H3: Companies belonging to the environmentally sensitive industry group as key stakeholders have a positive effect on the quality of social disclosure and the environment.

\section{Methodology}

The population in this study are companies listed on the Indonesia Stock Exchange participating in the PROPER program every year the 2014-2018 period will be made into an internal population this research. Study documentation will be used in this research by collecting online media, financial reports, annual reports, and company sustainability reports. The sample used by 17 companies and total observation of 85 companies with a maximum error of $5 \%$ and a level of reliability of 95\%. Data analysis techniques in this study used Eviews 10 by doing descriptive statistical analysis, panel data regression analysis and the above prerequisite tests the best model is chosen. Expected through the participation and consistency of management the company proactively follows the PROPER program to manage its environment and social affairs with maximum performance, so that company management can be compelled to disclose quality responsibility actions in annual reports or sustainability reports.

\section{Dependent Variable}

Content analysis is used to calculate the CSED quality disclosure index with score 0 if not revealed, score 1: disclose without explanation or the company only provides a statement regarding the disclosure indicators in a manner short, score 2: express and explain qualitatively and score 3: disclose and provide qualitative explanations and provide data in nominal terms (quantitative) figures for each indicator disclosed based on 91 GRI G4 indicators. The CSED disclosure index is obtained by dividing the number of CSED items disclosed by total disclosure items according to GRI-G4 (Anggraeni and Djakman, 2018).

\section{Independent and control variable}

The creditor pressure variable is measured by total debt divided by the total ratio (Lu and Abeysekera, 2014). Variable media coverage is measured based on the formula of the Janis-Fadner coefficient (Bansal and Clelland, 2004). Industry group variables are measured using dummy $1=$ Industry has a significant impact on the environment, $0=$ Other industries (Fernandez-feijoo, 2012). This research also uses control variables namely company size (Ln_Sales) and profitability (ROA).

\section{Result}

Table 1 Descriptive Statistics Test Results

\begin{tabular}{ccccccc} 
& \multicolumn{7}{c}{ Industry } \\
Mean & 0.598471 & 0.799882 & 0.955176 & 0.611765 & 6.974706 & 0.094111 \\
Median & 0.600000 & 0.670000 & 1.000000 & 1.000000 & 6.990000 & 0.050000 \\
Maximum & 0.850000 & 3.000000 & 1.000000 & 1.000000 & 7.800000 & 1.830000 \\
Minimum & 0.200000 & 0.060000 & -0.220000 & 0.000000 & 5.910000 & -0.150000 \\
Std. Dev & 0.180901 & 0.571042 & 0.176761 & 0.490241 & 0.500506 & 0.216803
\end{tabular}

Table 1 presents the results of the descriptive statistics of each of the research variables tested. Index QCSED disclosures come from Asahimas Tbk of 0.02 (2\%) and the maximum value obtained by Aneka Tambang Tbk of 0.85 $(85 \%)$. The lowest value is owned by a company that has not has published sustainability reports and many social and environmental issues not much is disclosed in the annual report. The highest value is owned by the company which is consistently published sustainability reports every year 2014-2018. That thing as assessment that differences in CSED disclosure rates between companies are using sustainability reports and annual reports based on the GRI G4 index. QCSED Disclosure has an average value of 0.59 (59\%) which means there is an increase in the quality of disclosure every year. The distribution of statistical data from the QCSED variable is 0.18 . The stakeholder pressure variable has a minimum value of 0.06 originating from IndospringTbk and a maximum value of 3.00 from MultiBintangTbk. Multibintang Tbk is a company with the highest level of debt but has a disclosure quality of 50\% due to a lack of disclosure items that are not explained quantitatively and qualitatively. While the average value of 0.79 with the distribution of statistical data of 0.57 . 
The media coverage variable has a maximum value for this variable is 1.000000 derived from Aneka Tambang Tbk due to the many social and environmental issues in the annual report, sustainability reports and media that cover, while the minimum value is 0.000000 originating from Indospring Tbk, which very few media cover social and environmental issues the company, both the company itself. The average value of 0.955176 with a standard deviation amounting to 0.17676 . The next independent variable is the environmentally sensitive industry group has an average value 0.611765 with a standard deviation of 0.490241 The maximum value for this variable is 1.000000 comes from Aneka Tambang which is classified as an environmentally sensitive industrial group expressing social and environmental issues quantitatively and qualitatively in the annual report and sustainability report, while the minimum value is -0.220000 from Asahimas Tbk. The average value of company size (SIZE) is 6,974706 with a standard deviation of 0.500506. The maximum value for this variable is 7.800000 from Semen Indonesia Tbk, meanwhile, the minimum value is 5.9100 originating from MultiBintang Tbk. The average value of ROA is 0.094111 with a standard deviation of 0.216803 and. The maximum value for ROA variables is 1.830000 originating from Bukit Asam Tbk, while the minimum value is - 0.150000 comes from PP London Sumatra Indonesia. In order to answer the research hypothesis established in this empirical research and verify the existing influence pressure of stakeholder creditor, media exposure and industry category on corporate social environment disclosure quality, a panel analysis by using the following model approach:

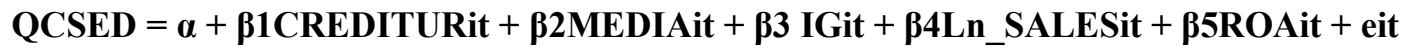 Influence of Pressure of Stakeholder Creditor, Media Exposure and Industry Category on $(\mathbf{n}=\mathbf{8 5})$}

\begin{tabular}{|c|r|r|r|r|}
\hline & & & & \\
\hline Variable & Coefficient & Std. Error & t-Statistic & Prob. \\
\hline C & -0.700532 & 0.340632 & -2.056563 & 0.0430 \\
\hline CREDITOR & -0.019016 & 0.029198 & -0.651265 & 0.5168 \\
\hline MEDIA & 0.015341 & 0.052696 & 0.291120 & 0.7717 \\
\hline INDUSTRY GROUP & 0.097209 & 0.023234 & 4.183954 & 0.0001 \\
\hline SIZE & 0.176511 & 0.048318 & 3.653109 & 0.0005 \\
\hline ROA & 0.095433 & 0.047856 & 1.994189 & 0.0496 \\
\hline R-squared & 0.310951 & \multicolumn{2}{|c|}{ Mean dependent var } & 0.176042 \\
\hline Adjusted R-squared & 0.267340 & \multicolumn{2}{|c|}{ S.D. dependent var } & 0.092855 \\
\hline S.E. of regression & 0.079480 & Sum squared resid & 0.499050 \\
\hline F-statistic & 7.130152 & \multicolumn{2}{|c|}{ Durbin-Watson stat } & 1.499102 \\
\hline Prob(F-statistic) & 0.000015 & \multicolumn{3}{|l}{} \\
\hline
\end{tabular}

The result of the show is that the adjusted $\mathrm{R} 2$ has a value of 0.267 which means the pressure variable creditors, media coverage and environmental industry groups are able to explain the dependent variable namely the quality of social and environmental disclosure (QCSED) of only $26.7 \%$. While $73.3 \%$ of the remainder is influenced by other factors outside the unselected research model as an independent variable. Furthermore, the $\mathrm{F}$ test shows a significance value of 0,000 at the level significance of $0.05(5 \%)$. The number indicates that the test is simultaneously entire independent variables and control variables have a significant effect on the dependent variable viz quality of social and environmental disclosure (QCSED).

\section{Conclusions and Discussion}

Companies belonging to the environmentally sensitive industry group have more quality in expressing social and environmental responsibility to their stakeholders. Size company and company profitability also have an influence on the quality of disclosure because of the bigger the company and the higher the profitability, the responsibility they become bigger to get legitimacy from their stakeholders, one of them the surrounding community so that they will make disclosures of social responsibility and higher quality environment. In addition to chasing profits, the company will also pay attention and involved in meeting the welfare of the people (people) and actively contribute to preserving the environment (planet). Variable pressure from creditor stakeholders and media coverage do not affect the duty of social and environmental disclosure. This is due to the assessment of the quality of social and environmental disclosure is not a major point in consider giving additional capital to the company and media coverage not giving rise to stakeholders not being too concerned about the quality of responsibility the company was caused by a small amount of media coverage and only major issues were covered. The companies that are used as research samples are only companies that consistently follow PROPER every year which is listed on the Indonesia Stock Exchange in 2014-2018 so that it is not represented all companies in Indonesia and the results cannot be generalized. At first, Companies that consistently follow PROPER are expected to have disclosure quality better society and environment. 
Lack of online media specifically covering business news and the economics of companies in Indonesia such as Economic Review, Economic News and etc. For further researchers to be expected to be able to expand the scope of research to remember this study only focused on Go public companies that consistently participated in PROPER the year.

Researchers can expand the scope of research in various sectors then. You can too add dependent variables or other control variables so that the value of $\mathrm{R}$ square in the statistical test can increase even greater than this research. Future researchers can add online media that specifically cover the business and economic news of companies in Indonesia such as Economic Review and Economic News so that more and more news obtained about the social and environmental issues of companies in Indonesia.

Tabel 1.1

Variations of CSR Disclosure In The Annual Report of Public Companies In Indonesia

\begin{tabular}{|c|c|c|c|c|}
\hline Researcher & Year & Sample & $\begin{array}{c}\text { Mean } \\
\text { CSR }\end{array}$ & Measure \\
\hline Sari (2012) & $2008-2010$ & Manufacture Company & $21 \%$ & GRI 3 (78 item) \\
\hline Kristi (2012) & $2010-2011$ & Public Company & $30 \%$ & GRI 3 (78 item) \\
\hline $\begin{array}{c}\text { Ekowati et al } \\
(2014)\end{array}$ & $2010-2012$ & Manufacture Company & $49 \%$ & GRI 3 (78 item) \\
\hline $\begin{array}{c}\text { Munsai et al } \\
(2016)\end{array}$ & $2010-2014$ & $\begin{array}{c}\text { Property dan Real Estate } \\
\text { Company }\end{array}$ & $49 \%$ & GRI 3 (78 item) \\
\hline $\begin{array}{c}\text { Solikhan dan } \\
\text { Winarsih } \\
(2016)\end{array}$ & $2011-2013$ & $\begin{array}{c}\text { Mining, Energy, Cosmetic, } \\
\text { Food and Beverage Company }\end{array}$ & $49 \%$ & $\begin{array}{c}\text { Environmental } \\
\text { disclosure index } \\
\text { (Rupley et al } \\
\text { (2012) }\end{array}$ \\
\hline $\begin{array}{c}\text { Indraswari } \\
(2017)\end{array}$ & $2012-2015$ & Company Food and Beverage & $30 \%$ & GRI 4 (91item) \\
\hline $\begin{array}{c}\text { Widiastuti et } \\
\text { al (2018) }\end{array}$ & $2014-2015$ & Public Company & $38 \%$ & GRI 3 (78 item) \\
\hline
\end{tabular}

Gambar 1.1

The Largest Countries Produce Plastic Waste

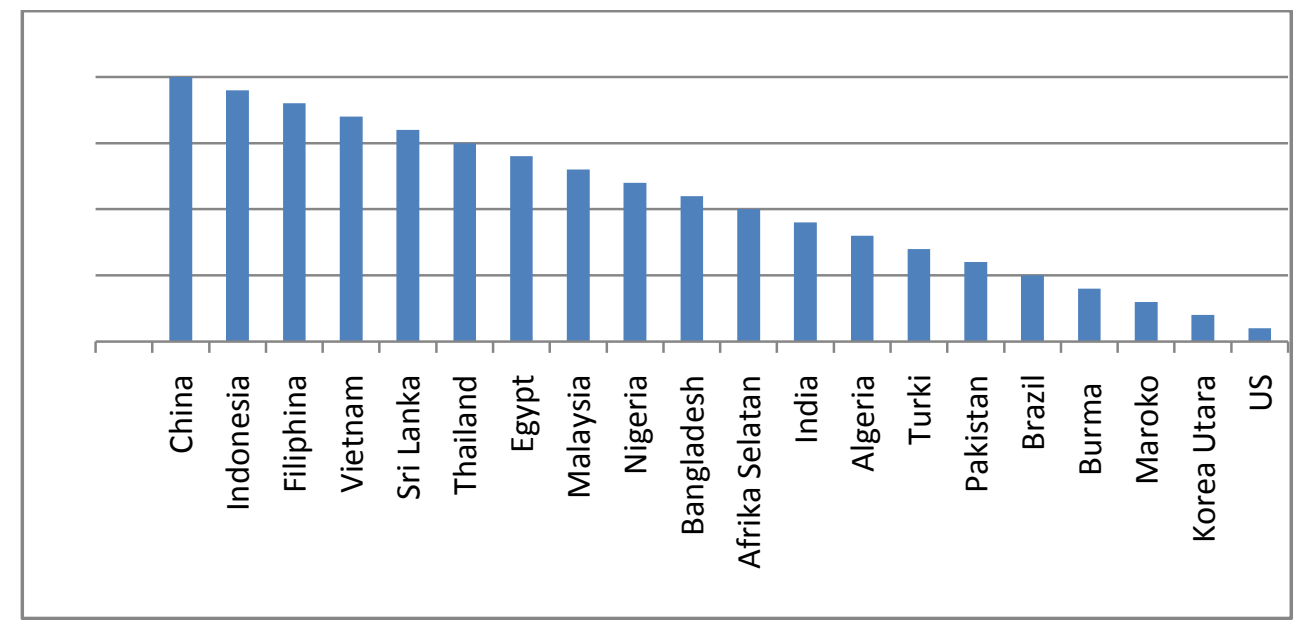

Source : Jambeck et al. (2015)

\section{Reference}

Anggraeni, Dian Yuni and Chaerul D. Djakman. 2018. "Pengujian Terhadap Kualitas Pengungkapan Csr Di Indonesia." (80):22-41.

Bani-khalid, Tareq, Reza Kouhy, and Aminu Hassan. 2017. "The Impact of Corporate Characteristics on Social and Environmental Disclosure ( CSED ): The Case of Jordan.” 2017.

Bansal, P. and I.Clelland. 2004. Talking'Trash':Legitimacy, Impression Management, and Unsystematic Risk in the Context of the Natural Environment. Academy of Management Journal, 47 (1), 93-103. 
Bewley, Ronald and William E. Griffiths. n.d. "Enetration Of.” (May 2000).

Deegan, Craig and Ben Gordon. 1996. "A Study of the Environmental Disclosure Practices of Australian Corporations." (February 2014):37-41.

Ekowati, Lilis, Prasetyono, and Anis Wulandari. 2014. "Pengaruh Profitabilitas, Likuiditas, Growth,Dan Media Exposure Terhadap Pengungkapan Tanggungjawab Sosial Perusahaan (Studi Pada Perusahaan Manufaktur Yang Terdaftar Di BEI Tahun 2010 - 2012).” Simposium Nasional Akuntansi 17 Mataram, Lombok, no. 40: $1-24$.

Fernandez-feijoo. 2012. "Effect of Stakeholders' Pressure on Transparency of Sustainability Reports within the GRI Framework." 53-63.

Gamerschlag. 2011. "Determinants of Voluntary CSR Disclosure : Empirical Evidence from Germany." 233-62.

Hasnia and Rofingatun. 2017. "Pengaruh Profitabilitas, Likuiditas , Growth Dan Media Exposure Terhadap Pengungkapan Tanggung Jawab Sosial Perusahaan.” 12(2014):56-71.

Hamudiana, Arum and Tarmizi Achmad. 2017. "Pengaruh Tekanan Stakeholder Terhadap Transparansi Laporan Keberlanjutan Perusahaan-." 6:1-11.

Indraswari, I Gusti Ayu Laksmi. 2017. "Pengaruh Profitabilitas, Pertumbuhan Perusahaan, Kapitalisasi Pasar Dan Kepemilikan Saham Publik Pada Tingkat Pengungkapan CSR." Udayana, E-Jurnal Akuntansi Universitas 20: 1219-48.

Jambeck, Jenna R. et al. 2015. "Plastic Waste Inputs from Land into the Ocean." 347(6223).

Kristi, Agatha Aprinda. 2012. "Faktor-Faktor Yang Mempengaruhi Pengungkapan Corporate Sosial Responsibility Pada Perusahaan Publik Indonesia.” Jurnal Ilmiah Mahasiswa FEB Universitas Brawijaya 1: 27

Lee, Seoki, Kwanglim Seo, and Amit Sharma. 2013. "Corporate Social Responsibility and Fi Rm Performance in the Airline Industry : The Moderating Role of Oil Prices.” Tourism Management 38:20-30.

Lindawati, Lin and Marsella Eka Puspita. 2015. "Corporate Social Responsibility: Implikasi Stakeholder Dan Legitimacy Gap Dalam Peningkatan Kinerja Perusahaan.” 157-74.

Lu, Yingjun and Indra Abeysekera. 2014. "Stakeholders ' Power, Corporate Characteristics , and Social and Environmental Disclosure : Evidence from China." 426-36.

Macarulla, Fernando Llena and Mohammad Ahmad Talalweh. 2012. "Voluntary Corporate Social Responsibility Disclosure : A Case Study of Saudi Arabia." 8(4):815-30.

Mansor, Noorhayati, Abdullah Wan, A. Bahari, and AF Hassan Shukri. 2016. "Palm Oil Sustainability Certification and Firm Performance: Is There a Conflict Between RSPO and MSPO?"

Munsaidah, Siti, Rita Andini, and Agus Supriyanto. 2016. "Analisis Pengaruh Firm Size, Age, Profitabilitas, Leverage, Dan Growth Perusahaan Terhadap Corporate Social Rerponsibility (CSR) Pada Perusahaan Property Dan Real Estate Yang Terdaftar Di Bursa Efek Indonesia Pada Tahun 2010-2014.” Journal of Accounting 2 (2)

Nguyen, La Soa, Manh Dung Tran, Thi Xuan, Hong Nguyen, and Quoc Hoi Le. 2017. "Factors Affecting Disclosure Levels of Environmental Accounting Information : The Case of Vietnam." 6(4):255-64.

Panjaitan, Julianto Manangar. 2015. "Pengaruh Tanggungjawab Sosial Perusahaan Terhadap Nilai Perusahaan Dengan Profitabilitas Sebagai Variabel Intervening Dan Moderating (Studi Empris Pada Perusahaan Manufaktur Yang Terdaftar Di Bei)." VI(01):54-81.

Patten, Dennis M. 1992. "Intra-Industry Environmental Disclosures In Response To The Alaskan Oil Spill: A Note On Legitimacy Theory." 17(5):471-75.

Purnasiwi. 2011. "Leverage Terhadap Pengungkapan Csr Pada Perusahaan Yang Terdaftar Di Bursa Efek Indonesia."

Reverte, Carmelo. 2009. "Determinants of Corporate Social Responsibility Disclosure Ratings by Spanish Listed Firms." Journal of Business Ethics 88(2):351-66.

Roberts, Robin W. 1992. "Determinants Of Corporate Social Responsibility Disclosure: An Application Of Stakeholder Theory." 17(6).

Rupley, Kathleen Hertz, Darrell Brown, and R. Scott Marshall. 2012. "Governance, Media and the Quality of Environmental Disclosure.” Journal of Accounting and Public Policy 31(6):610-40.

Sanghiata, Bhattacharya, Anns Issac, Preety Rajbangshi, Aradhana Srivastava, and Bilal Avan. 2015. ““ Neither We Are Satisfied nor They' -Users and Provider's Perspective: A Qualitative Study of Maternity Care in Secondary Level Public Health Facilities , Uttar Pradesh , India." 15.

Sari, Rizkia Anggita. 2012. "Pengaruh Karakteristik Perusahaan Terhadap Corporate Social Responsibility Disclosure Pada PerusahaanManufaktur Yang Terdaftar Di Bursa Efek Indonesia.” Nominal I (I): 124-40.

Solikhah, Badiangtus dan Wirnasih, Arga. 2016. "Pengaruh Liputan Media, Kepekaan Industri, Dan Struktur Tata Kelola Perusahaan Terhadap Kualitas Pengungkapan Lingkungan." Akuntansi Dan Keuangan Indonesia 13(1):1-22. 
Tan, Andreas, Desmiyawati Benni, and Warda Liani. 2016. "Determinants of Corporate Social Responsibility Disclosure and Investor Reaction." 6:11-17.

Ulmann, A. 1985. "In of a Theory: Search RelationshIps of the ACritical Examatina Ion Social Among Performance Disclosure , And." 10(3):540-57.

Wang, Bo and Hua-ming Wang. 2018. "Media Attention, Executive Reputation and Corporate Social Responsibility-Empirical Evidence from Chinese A-Share Listed Companies." 6(1):42-48.

Widiastuti, Harjanti, Evy Rahman Utami, Ridi Handoko, and Universitas Muhammadiyah Yogyakarta. 2018. "Pengaruh Ukuran Perusahaan, Tipe Industri , Growth, Dan Media Perusahaan ( Studi Empiris Pada Perusahaan Yang Terdaftar Di Bursa Efek Indonesia Tahun 2014- Riset Akuntansi Dan Keuangan Indonesia , 3 ( 2 ), 2018." 3(25):107-17. 